\title{
Phenotypic Characterization of Indigenous Sheep Types in Bale Zone, Oromia Regional State, Ethiopia
}

\author{
Belete Asefa ${ }^{*}$, Tadesse Abate ${ }^{1}$ and Eshetu Adugna ${ }^{2}$
}

${ }^{1}$ Department of Animal and Range Sciences, School of Agriculture, Madda Walabu University, PO Box 247, Bale Robe, Ethiopia

${ }^{2}$ Department of Animal and Range Sciences, Sinana District Livestock and Fishery Production, Ethiopia

\begin{abstract}
This study was aimed to generate organized information on physical characteristics and prediction of live weight using linear body measurements of indigenous sheep types in five districts of Bale zone (Agarfa, Dinsh, Goba, Sawena and Dawe Kechan). The study was based on field measurements. Multistage purposive sampling was used for selection of districts. Three kebeles from each districts were sampled using simple random sampling techniques. About 600 matured sheep ( 540 female and 60 male) sheep were sampled for body measurements and qualitative character based on four age category (1 PPI, 2 PPI, 3 PPI and 4 PPI). Both qualitative and quantitative data were analyzed using Statistical analysis system. On the identified dimensions, the sheep population in highland district were found within the same region of space and were clustered with long tailed, no toggle, black and red coat color, no wattle, lateral ear form and forward and upright horn orientation while sheep in Sawena and Dawe kechan were characterized as patch coat color pattern with black and white color, polled horn, dropped ear form, fat rumped tail type, concave head profile and absence of toggle and presence of wattle. The highest correlation between chest girth and body weight both for male and female sheep indicate that chest girth is the best variable for predicting live weight than other measurements. The overall mean of body weight, body length, heart girth, wither height, pelvic width, ear length, rump height, rump length, rump width and head length were $26 \mathrm{Kg}, 48.75 \mathrm{~cm}, 71.4$ $\mathrm{cm}, 62.1 \mathrm{~cm}, 16.32 \mathrm{~cm}, 11.1 \mathrm{~cm}, 63.66 \mathrm{~cm}, 14.04 \mathrm{~cm}, 16.86 \mathrm{~cm}$ and $9.11 \mathrm{~cm}$, respectively. The best predicted body weight (BW) Model for female sheep is $-13.53+0.40 \mathrm{HG}+0.25 \mathrm{BL}-0.17 \mathrm{HL}$ and Model for male sheep (BW) is $-13.66+0.41 \mathrm{HG}+0.39 \mathrm{SC}+0.27 \mathrm{RL}-0.11 \mathrm{PW}$. The present phenotypic characterization reveals that, the existence of diversity of sheep genetic resource across different agro-ecologies. Arsi bale sheep breed is distributed in highland districts and black head Somali sheep is distributed in lowlands of bale zone.
\end{abstract}

Keywords: Bale zone; Characterization; Indigenous sheep types; Phenotypic traits

\section{Introduction}

Ethiopia has diverse indigenous sheep breeds, at least 9 breeds and 14 traditional sheep populations, distributed across diverse ecology, production systems and communities or ethnic groups [1]. As a result of their wide range of habitat, behavioral and reproductive adaptations, sheep have evolved into a large number of different geographically separate phenotypic forms or races varying in size, fleeces, conformation, muscling and coat color. Despite low level of productivity due to several factors such as genotype, environmental and institutional constraints [2] indigenous sheep breeds have a great potential to contribute more to the livelihood of people in low input, small holder and pastoral production systems [3].

Identification and characterization of livestock genetic resources and their production environment is vital for long-term genetic improvement and sustained use of available resources [4]. In Ethiopia, only few breeds have a fair description of their physical appearance [5]. Characterizing the existing sheep production systems and analyzing their production constraints are important tools to diagnose the status and trends of the system, and thus to identify areas for future interventions [6]. Classical description of breeds is based upon phenotype because an organism's phenotype is principally a manifestation of its genotype, and that it lends itself to direct measurement on the organism. As such, phenotypic characterization is therefore complementary to the powerful biotechnological techniques for measuring genetic diversity on the genome [5].

Information on body weight with several body measurements is necessary not only to monitor the growth of the sheep but also to estimate genetic correlations between body weight and body measurements. These measurements provide important evidences for the growth of the breed and the properties that change with environmental effects and feeding factors. In addition, body measurements are important data sources in terms of reflecting the breed standards [7] and are important in giving information about the morphological structure and development ability of the animals. Body weight is measured is also important to determine suitable medication dosage during health care and required feed amount of the animal [8] as indicator of breed standards great convenience for the prediction of body weight without weighbridges $[9,10]$.

In general, Information on phenotypic traits of sheep type in the bale zone is limited despite its contribution and role as source of cash income and improving food security in both lowland and highlands of bale zone. Local breeds are also a source of genetic diversity needed by modern livestock production to ensure stability and continuity. In addition, if there are previous works supposedly done, updating of previous results is vital since genetic resources and production systems

${ }^{*}$ Corresponding author: Belete Asefa, Department of Animal and Range Sciences, School of Agriculture, Madda Walabu University, PO Box 247, Bale Robe, Ethiopia, Tel: +251924894687; E-mail: beleteasefa@gmail.com

Received March 29, 2017; Accepted June 16, 2017; Published June 17, 2017

Citation: Asefa B, Abate T, Adugna E (2017) Phenotypic Characterization of Indigenous Sheep Types in Bale Zone, Oromia Regional State, Ethiopia. J Vet Sci Technol 8: 452. doi: 10.4172/2157-7579.1000452

Copyright: @ 2017 Asefa B, et al. This is an open-access article distributed under the terms of the Creative Commons Attribution License, which permits unrestricted use, distribution, and reproduction in any medium, provided the original author and source are credited. 
are not static, routine inventories and on-going monitoring. Thus, more detailed characterization study of Bale sheep and its production system are required. Hence, this study was attempted to physically characterize indigenous sheep types in Bale zone, Oromia Region, Ethiopia.

\section{Materials and Methods}

\section{Description of study area}

The study was conducted in three districts of bale highlands (Agarfa, Dinsho and Goba) and two districts of bale lowlands (Sawena and Dawe kechan) in year of 2015/2016. Bale zone have 9 highland districts, 9 lowland districts and two town administrative. The zone falls between latitude $5^{\circ} 22^{\prime}-8^{\circ} 08^{\prime} \mathrm{N}$ and longitudes $38^{\circ} 41^{\prime}-40^{\circ} 44^{\prime} \mathrm{E}$. The total land area of the Zone is $69,661 \mathrm{~km}^{2}$, which ranked the zone as the largest zone in Oromia National Regional States. The zone have about 2,825,215 cattle, 528,746 sheep, $1,405,715$ goats, 300,077 horse, 49,657 mule, 170,153 donkey, 244,073 camel and 747,662 chicken [11].

\section{Source of animal and management}

All indigenous sheep type found in study districts of bale zone was used as source of animal. Since it is on farm characterization, animals in hands of farmers was used and data regarding body measurement and morphometric characteristics were collected early in the morning before animal release the burn and fed any feed.

\section{Sample size and sampling techniques}

For Morphological characters (qualitative) and body measurements (quantitative) about 600 sheep (540 female and 60 males) was selected based on sex and age of animals from sheep herds of 300 Household. Pregnant females (ewes) was excluded in sampling because of pregnancy have influence on body parameters. Animals should be selected from herds of sheep by considering distances between the herd and family houses to clearly get different animals. Each experimental animal was identified by sex, site, flock number and estimated age group. There is the effect of age and sex on body weight and linear body measurements. All age group sheep were classified into five age groups such as no pair of permanent incisor (1 PPI, 2 PPI, 3 PPI and 4 PPI).

\section{Data collection}

Data was recorded on the prepared format adopted from the standard description list developed by FAO [12] and of ILRI-OADB breed descriptor list [13]. All the data was taken early in the morning since body measurements are influenced by posture, motion and gut content of the animals.

Morphological characters like: coat color type and pattern, hair type, head profile, ears shape, ear orientation, wattle, horn shape, horn orientation, ruff and tail type was studied with naked eye observation. Body measurements $(\mathrm{cm})$ such as Chest Girth (CG), Body Length (BL), Height at Wither (WH), Rump Height (RH), Rump Length (RL), Rump Width (RW), Pelvic Width (PW), Thoracic Depth (TD), Ear Length (EL), Horn Length (HL), Tail Length (TL), Tail Circumference (TC), Scrotum circumference (SC) and Teat Length (TL) were measured using tailors measuring tape with records taken to the nearest $\mathrm{cm}$ after restraining and holding the animal in an unforced position. Weight was measured in the morning before their release for feeding to minimize post-prandial gut variation and measured using suspended spring balance having $50 \mathrm{~kg}$ capacity with $0.2 \mathrm{~kg}$ precision (Figure 1 ).

\section{Data management and statistical analysis}

All the collected data were coded and recorded in Microsoft excel spread sheet. Qualitative data from individual observation was analyzed following the frequency procedures of SAS version 9.1, 2003). Chi-square test was employed to test the assumption of equal proportion between the categorical variables.

Observations on morphological characters were analyzed for male and female sheep using frequency procedure of Statistical Analysis System (SAS, release 9.1, 2003). Means, standard deviations, standard errors and coefficients of variation was computed for all the quantitative traits measured using the General Linear Procedure (GLM) of SAS statistical Analysis System (SAS, release 9.1, 2003). For adult animals, sex and age group of the experimental sheep was fitted as fixed independent variables while body weight and linear body measurements except scrotum circumference and was fitted as dependent variables. Scrotum circumference was analyzed by fitting age group as fixed factor. When analysis of variance declares significance, least square means was separated using adjusted Tukey-Kramer test. The model employed for analyses of body weight and other linear body measurements except scrotum circumference and teat length were:

$$
\mathrm{Y}_{i j k}=\mu_{\mathrm{i}}+\mathrm{A} i+D j+D k+\mathrm{e}_{i j k}
$$

where, $\mathrm{Y}_{i j k}=$ the observed $k$ (body weight or linear body measurements) in the $i^{\text {th }}$ age group, $j^{\text {th }}$ Sex and $\mathrm{k}^{\text {th }}$ districts; $\mu_{\mathrm{i}}=$ Overall mean; $\mathrm{A}_{i}=$ the effect of $i^{\text {th }}$ age group ( $i=1$ PPI, 2 PPI, 3 PPI and 4 PPI) $D_{j}=$ the effect of $j^{\text {th }}$ Sex $(j=1$ and 2$)$; Dk=the effect of $k^{\text {th }}$ district (Goba, Agarfa, Dinsho, Dawe kachen and Sawena); eijk=random residual error.

Pearson's correlation coefficients for each trait were estimated between body weight and other body measurements within sex and age group (SAS, Release 9.1, 2003). Within each age group, stepwise regression procedure (SAS, release 9.1, 2003) was used to determine the best-fitted regression equation for the prediction of body weight from body measurements. Similar stepwise regression was employed for females within each age group by excluding SC from the model. Best-fitted models was selected based on coefficient of determination $\left(\mathrm{R}^{2}\right)$, mean square error and simplicity of measurement under field condition. The following models were used for the analysis of multiple linear regressions.

\section{For male:}

$\Upsilon j=\alpha+\beta X 1+\beta X 2+\beta \ldots \ldots+\beta n X n+e j$

Where: $Y j=$ the response variable (body weight)

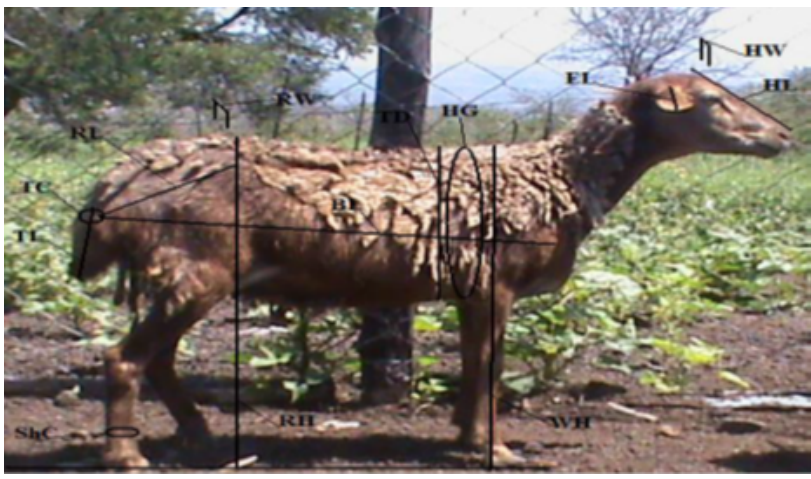

Figure 1: Morphometric variables studied and their reference points. Notes: BW: Body weight; HG: Heart girth; WH: Wither height; RH: Rump height TD: Thorax depth; BL: Body length; TL: Tail length; TC: Tail circumference; HL: Head length; HW: Head width; ShC: Shin circumference; EL: Ear length; RW: Rump width; RL: Rump length. 
$\alpha=$ the intercept

$X 1, X 2, X 3, X 4, X 5, X 6$ and $X n=$ are the explanatory variables (body length, height at wither, chest girth, tail length, tail circumference, scrotal circumference and body condition, respectively). , n)

$\beta 1, \beta 2, \ldots, \beta_{\mathrm{n}}$ is regression coefficient of the variables $X(X 1, X 2, \ldots$

$e j=$ the residual random error.

\section{For female:}

$Y_{j}=\alpha+\beta X 1+\beta X 2+\ldots \ldots \beta_{n} X_{n}+\mathrm{ej}$

Where: $Y j=$ the dependent variable body weight

$\alpha=$ the intercept

$X 1, X 2, X 3, X 4, X 5$ and $X_{n}$ are the independent variables; body length, height at wither, chest, girth, tail length, tail circumference and body condition, respectively.

$\beta 1, \beta 2, \ldots, \beta \mathrm{n}$ is regression coefficient of the variable $X 1, X 2, \ldots, \mathrm{X}_{\mathrm{n}}$ $\mathrm{ej}=$ the residual random error.

\section{Results and Discussion}

\section{Characterization of physical traits}

Physical body characteristics of sheep population in highland and lowland of bale zone are presented in Table 1 and Figure 3. The results show that the presence of clear morphological variations between and within these indigenous sheep types. According to the report of Solomon there are high morphological, ecological, ethnic and production systems diversity of indigenous sheep distributions in Ethiopia [14]. The result of Yakubu points out that phenotypes are an expression of genetic characteristics, modified by environmental conditions and that variance in both genetics and environment may affect phenotypic variance [15]. It is in the context of these assertions that this study exclusively depended on morphometric measurements, geographic locations and qualitative traits to unravel the characteristic of genetic diversity amongst sheep types, which is most relevant for managing the present and future genetic diversity of the breed.

There were varied coloration patterns amongst the sheep populations sampled with predominantly patch (67.8\%) followed by spotty $(20.2 \%)$ of various colors. The most dominant coat colors of sheep in highland (Agarfa, Dinsho and Goba) were red while for lowland (white on body part and black color on their head). Majority of sheep population have no horn (polled) $(49.4 \%$ ) of which about $79.7 \%$ were found in lowland. The predominant ear form is dropped $(53.3 \%)$ followed by (46.5\%). They are mainly characterized by absence of toggle (95.3\%), absence of wattle (59.2\%), absence of ruff (98\%) and absence of muzzle (97.5\%). They are also characterized as having flat head profile $(82.5 \%)$. The main tail types were fat tailed (57\%) of which about $95 \%$ are from highland. Sheep in low land (Sawena and Dawe Kachen) were characterized as fat rumped $(100 \%)$.

A multiple correspondence analysis was carried out on the twelve qualitative traits recorded and a bi-dimensional graph representing the associations among the different categories of qualitative traits is presented in Figure 2. The interpretation is based on points found in approximately the same direction from the origin and in approximately the same region of the space. From the figure it can be seen that $18.4 \%$ of the total variation is explained by the first two dimensions (10.2\%) by the first and (8.2\%) by the second dimensions.

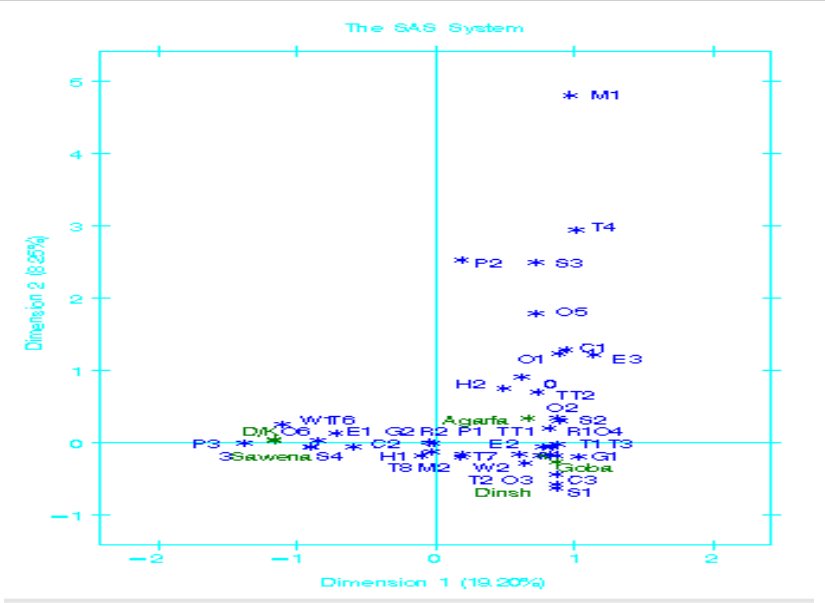

Figure 2: Bi-dimensional plot showing the associations among the categories of the different morphological variables.
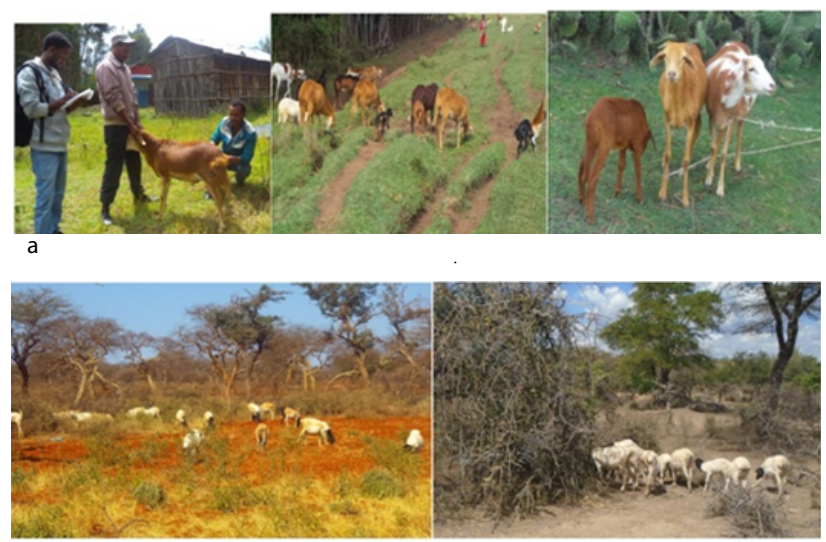

b

Figure 3: a) Typical example of bale highland sheep.b) Typical example of bale Lowland sheep.

On the identified dimensions, the sheep population in highland district were found within the same region of space and were clustered with fat tailed, no toggle, black and red coat color, no wattle, lateral ear form and forward and upright horn orientation while sheep in Sawena and Dawe kechan were characterized as patch coat color pattern with black and white color, polled horn, dropped ear form, fat rumped tail type, concave head profile and absence of toggle and presence of wattle. The result of qualitative characterization revealed that there were diversified sheep breeds in bale zone. Around highlands of Bale zone, Arsi Bale sheep were distributed while around lowlands Blackhead Somali sheep were distributed.

\section{Correlation between body weight and linear body measurements}

The association between body weight and linear body measurements for male and female sample sheep population was presented in Table 2 . In male's positive and strong association were found between body weight and other linear body measurements. The associations are chest girth $(\mathrm{r}=0.82)$, wither height $(\mathrm{r}=0.74)$, body length $(\mathrm{r}=0.74)$. In females also chest girth $(\mathrm{r}=0.86)$, body length $(\mathrm{r}=0.74))$, rump height $(r=0.48)$, among the body measurements, chest girth was the most strongly correlated trait with body weight ( $\mathrm{r}=0.96$ for males; $\mathrm{r}=0.97 \mathrm{for}$ females). This highest association of chest girth with body weight than 
Citation: Asefa B, Abate T, Adugna E (2017) Phenotypic Characterization of Indigenous Sheep Types in Bale Zone, Oromia Regional State, Ethiopia. J Vet Sci Technol 8: 452. doi: 10.4172/2157-7579.1000452

Page 4 of 7

\begin{tabular}{|c|c|c|c|c|c|c|c|}
\hline \multicolumn{8}{|c|}{ District } \\
\hline & & Agarfa & Dinsho & Goba & Sawena & D/K & \\
\hline Character & Attribute & $N(\%)$ & $N(\%)$ & $N(\%)$ & $N(\%)$ & $N(\%)$ & Overall \\
\hline Coat color pattern & $\begin{array}{c}\text { Plain } \\
\text { Spotted } \\
\text { Patchy } \\
\mathrm{X}^{2} \text {-Value }\end{array}$ & $\begin{array}{l}23(19.2) \\
38(31.7) \\
59(49.1)\end{array}$ & $\begin{array}{l}20(16.7) \\
47(39.2) \\
53(44.1)\end{array}$ & $\begin{array}{c}29(24.2) \\
36(30) \\
55(45.8)\end{array}$ & $\begin{array}{c}- \\
- \\
120(100)\end{array}$ & $\begin{array}{c}- \\
- \\
120(100)\end{array}$ & $\begin{array}{c}72(12) \\
121(20.2) \\
407(67.8) \\
269.25^{\star \star}\end{array}$ \\
\hline Coat color type & $\begin{array}{c}\text { Black } \\
\text { White } \\
\text { Red } \\
\text { Grey } \\
\text { Bla+whit } \\
\text { Bla+red } \\
\text { Whit+red } \\
\text { X²-Value }^{2}\end{array}$ & $\begin{array}{c}10(8.33) \\
1(0.8) \\
59(49.2) \\
5(4.2) \\
11(9.2) \\
10(8.3) \\
24(20)\end{array}$ & $\begin{array}{c}15(12.5) \\
6(5) \\
33(27.5) \\
1(0.8) \\
15(12.5) \\
11(9.2) \\
39(32.5)\end{array}$ & $\begin{array}{c}9(7.5) \\
7(5.8) \\
35(29.2) \\
10(8.3) \\
26(21.7) \\
3(2.5) \\
30(25)\end{array}$ & $\begin{array}{c}- \\
3(2.5) \\
- \\
- \\
103(85.8) \\
- \\
14(11.7)\end{array}$ & $\begin{array}{c}- \\
5(4.2) \\
- \\
- \\
92(76.7) \\
- \\
23(19.1)\end{array}$ & $\begin{array}{c}34(5.7) \\
22(3.7) \\
127(21.1) \\
16(2.7) \\
247(41.1) \\
24(4) \\
130(21.7) \\
352.35^{\star *}\end{array}$ \\
\hline Hair Type & $\begin{array}{c}\text { smooth } \\
\text { curl } \\
\mathrm{X}^{2} \text {-Value }\end{array}$ & $\begin{array}{l}89(74.2) \\
31(25.8)\end{array}$ & $\begin{array}{l}87(72.5) \\
33(27.5)\end{array}$ & $\begin{array}{c}102(85) \\
18(15)\end{array}$ & $\begin{array}{c}106(88.3) \\
14(11.7)\end{array}$ & $\begin{array}{c}109(90.8) \\
11(9.2)\end{array}$ & $\begin{array}{c}493(82.2) \\
107(17.8) \\
418.05^{\star *}\end{array}$ \\
\hline Horn shape & $\begin{array}{l}\text { Straight } \\
\text { Curved } \\
\text { Spiral } \\
\text { Polled } \\
X^{2} \text {-Value }\end{array}$ & $\begin{array}{c}28(23.33) \\
47(39.17) \\
10(8.33) \\
35(29.17)\end{array}$ & $\begin{array}{c}53(44.17) \\
50(41.67) \\
8(6.67) \\
9(7.5)\end{array}$ & $\begin{array}{c}62(51.67) \\
36(30) \\
6(5) \\
16(13.33)\end{array}$ & $\begin{array}{c}- \\
3(2.5) \\
- \\
117(97.5)\end{array}$ & $\begin{array}{c}- \\
1(0.8) \\
- \\
119(99.2)\end{array}$ & $\begin{array}{c}143(23.8) \\
137(22.8) \\
24(4) \\
296(49.4) \\
418.05^{\star *}\end{array}$ \\
\hline Horn orientation & $\begin{array}{c}\text { Backward } \\
\text { Upward } \\
\text { Lateral } \\
\text { Forward } \\
\text { Downward } \\
\text { Polled } \\
\text { X²-Value }^{2}\end{array}$ & $\begin{array}{c}18(15) \\
36(30) \\
32(26.67) \\
- \\
- \\
34(28.33)\end{array}$ & $\begin{array}{c}13(10.8) \\
24(20) \\
58(48.33) \\
11(9.17) \\
5(4.17) \\
9(7.5)\end{array}$ & $\begin{array}{c}9(7.5) \\
23(19.17) \\
64(53.33) \\
- \\
8(6.67) \\
16(13.33)\end{array}$ & $\begin{array}{c}- \\
1(0.83) \\
2(1.67) \\
- \\
- \\
117(97.5)\end{array}$ & $\begin{array}{c}- \\
- \\
1(0.83) \\
- \\
1(0.83) \\
118(98.33)\end{array}$ & $\begin{array}{c}40(6.7) \\
84(14) \\
157(26.2) \\
11(1.8) \\
14(2.3) \\
294(49) \\
467.21^{* *}\end{array}$ \\
\hline Ear form & $\begin{array}{c}\text { Dropped } \\
\text { Lateral } \\
\text { Upward } \\
\text { X²-Value }^{2}\end{array}$ & $\begin{array}{c}54(45) \\
66(55) \\
-\end{array}$ & $\begin{array}{c}7(5.8) \\
112(93.33) \\
1(0.83)\end{array}$ & $\begin{array}{c}27(22.5) \\
93(77.5) \\
-\end{array}$ & $\begin{array}{c}117(97.5) \\
3(2.5) \\
-\end{array}$ & $\begin{array}{c}115(95.83) \\
5(4.17) \\
-\end{array}$ & $\begin{array}{c}320(53.3) \\
279(46.5) \\
1(0.2) \\
341.72^{\star *}\end{array}$ \\
\hline Toggle & $\begin{array}{c}\text { Present } \\
\text { Absent } \\
\mathrm{X}^{2} \text {-Value }\end{array}$ & $\begin{array}{c}5(4.17) \\
115(95.83)\end{array}$ & $\begin{array}{c}11(9.17) \\
109(90.83)\end{array}$ & $\begin{array}{c}12(10) \\
108(90)\end{array}$ & $\begin{array}{c}- \\
120(100)\end{array}$ & $\begin{array}{c}- \\
120(100)\end{array}$ & $\begin{array}{c}28(4.7) \\
572(95.3) \\
24.95^{\star *}\end{array}$ \\
\hline Ruff & $\begin{array}{c}\text { Present } \\
\text { Absent } \\
\mathrm{X}^{2} \text {-Value }\end{array}$ & $\begin{array}{c}6(5) \\
114(95)\end{array}$ & $\begin{array}{c}4(3.33) \\
116(96.67)\end{array}$ & $\begin{array}{c}2(1.67) \\
118(98.33)\end{array}$ & $\begin{array}{c}- \\
120(100)\end{array}$ & $\begin{array}{c}- \\
120(100)\end{array}$ & $\begin{array}{c}12(2) \\
588(98) \\
16.27^{\star *}\end{array}$ \\
\hline Muzzle & $\begin{array}{c}\text { Present } \\
\text { Absent } \\
X^{2} \text {-Value }\end{array}$ & $\begin{array}{c}15(12.5) \\
105(87.5)\end{array}$ & $\begin{array}{c}- \\
120(100)\end{array}$ & $\begin{array}{c}- \\
120(100)\end{array}$ & $\begin{array}{c}- \\
120(100)\end{array}$ & $\begin{array}{c}- \\
120(100)\end{array}$ & $\begin{array}{c}15(2.5) \\
585(97.5) \\
61.53^{\star *}\end{array}$ \\
\hline Wattle & $\begin{array}{c}\text { present } \\
\text { absent } \\
\mathrm{X}^{2} \text {-Value }\end{array}$ & $\begin{array}{c}11(9.17) \\
109(90.83)\end{array}$ & $\begin{array}{c}2(1.67) \\
118(98.33)\end{array}$ & $\begin{array}{c}- \\
120(100)\end{array}$ & $\begin{array}{c}117(97.5) \\
3(2.5)\end{array}$ & $\begin{array}{c}115(95.83) \\
5(4.17)\end{array}$ & $\begin{array}{c}245(40.8) \\
355(59.2) \\
518.56^{\star *}\end{array}$ \\
\hline Head profile & $\begin{array}{c}\text { Flat } \\
\text { concave } \\
\text { convex } \\
\mathrm{X}^{2} \text {-Value }\end{array}$ & $\begin{array}{c}108(90) \\
12(10) \\
-\end{array}$ & $\begin{array}{c}118(98.33) \\
1(0.83) \\
1(0.83)\end{array}$ & $\begin{array}{c}114(95) \\
6(5) \\
-\end{array}$ & $\begin{array}{c}80(66.67) \\
6(5) \\
34(28.33)\end{array}$ & $\begin{array}{c}75(62.5) \\
6(5) \\
39(32.5)\end{array}$ & $\begin{array}{c}495(82.5) \\
31(5.2) \\
74(12.3) \\
132.95^{\star *}\end{array}$ \\
\hline Tail type & $\begin{array}{l}\text { Fat tailed } \\
\text { Long tailed } \\
\text { Fat rumped } \\
X^{2} \text {-Value }\end{array}$ & $\begin{array}{c}114(95) \\
6(5) \\
-\end{array}$ & $\begin{array}{c}110(91.67) \\
10(8.33) \\
-\end{array}$ & $\begin{array}{c}118(98.33) \\
2(1.67) \\
-\end{array}$ & $\begin{array}{c}- \\
- \\
120(100)\end{array}$ & $\begin{array}{c}- \\
- \\
120(100)\end{array}$ & $\begin{array}{c}342(57) \\
18(3) \\
240(40) \\
603.96^{\star *}\end{array}$ \\
\hline
\end{tabular}

$\mathrm{N}=$ Number of sheep exhibiting a particular qualitative character; ${ }^{* *} \mathrm{p}<0.01 ;{ }^{*} \mathrm{P}<0.05 ; \mathrm{ns}=\mathrm{p}>0.05 ; \mathrm{X}^{2}=\mathrm{Pearson}$ chi-square; $\mathrm{D} / \mathrm{K}=\mathrm{Dawekechan}$

Table 1: Qualitative traits of sheep type in study area 


\begin{tabular}{|c|c|c|c|c|c|c|c|c|c|c|c|}
\hline & BL & BW & HG & WH & PW & RH & RL & RW & HL & EL & TtL \\
\hline BL & & $0.74^{\star *}$ & $0.64^{* *}$ & $0.49^{* *}$ & $0.24^{* *}$ & $0.40^{\star *}$ & $0.042 \mathrm{~ns}$ & $0.45^{* *}$ & $0.46^{* *}$ & $-0.15 n s$ & $0.32^{* *}$ \\
\hline BW & $0.74^{* *}$ & & $0.86^{\star *}$ & $0.48^{* *}$ & $0.31^{* *}$ & $0.49^{* *}$ & $0.07 \mathrm{~ns}$ & $0.51^{* *}$ & $0.45^{\star *}$ & $-0.07 n s$ & $0.41^{* *}$ \\
\hline HG & $0.74^{* *}$ & $0.82^{* \star}$ & & $0.49^{* *}$ & $0.32^{* *}$ & $0.48^{* *}$ & $0.11^{* *}$ & $0.52^{* *}$ & $0.52^{* *}$ & $-0.08 n s$ & $0.48^{* *}$ \\
\hline WH & $0.60^{* *}$ & $0.74^{\star *}$ & $0.70^{* *}$ & & $0.09 \mathrm{~ns}$ & $0.69^{* *}$ & $0.25^{\star *}$ & $0.43^{* *}$ & $0.41^{* *}$ & $0.03 \mathrm{~ns}$ & $0.20^{* *}$ \\
\hline PW & $0.06 \mathrm{~ns}$ & $0.03 \mathrm{~ns}$ & $0.25 \mathrm{~ns}$ & $0.14 \mathrm{~ns}$ & & $0.08 \mathrm{~ns}$ & $0.04 \mathrm{~ns}$ & $0.22^{* *}$ & $0.41^{* *}$ & $-0.18 n s$ & $0.06 n s$ \\
\hline $\mathbf{R H}$ & $0.65^{\star *}$ & $0.69^{\star \star}$ & $0.73^{* *}$ & $0.82^{* *}$ & $0.20 \mathrm{~ns}$ & & $0.38^{* *}$ & $0.46^{* *}$ & $0.33^{* *}$ & $0.10 \mathrm{~ns}$ & $0.23^{* *}$ \\
\hline $\mathbf{R L}$ & $0.16 \mathrm{~ns}$ & $0.41^{* *}$ & $0.24 \mathrm{~ns}$ & $0.21 \mathrm{~ns}$ & $-0.14 n s$ & $0.47^{* *}$ & & $0.13^{* *}$ & $0.09^{*}$ & $0.10 \mathrm{~ns}$ & $0.06 n s$ \\
\hline RW & $0.36^{\star *}$ & $0.39^{* *}$ & $0.48^{* *}$ & $0.37^{* *}$ & $0.01 \mathrm{~ns}$ & $0.47^{* *}$ & $0.21 \mathrm{~ns}$ & & $0.27^{* *}$ & $0.07 n s$ & $0.29^{* *}$ \\
\hline $\mathrm{HL}$ & $0.09 \mathrm{~ns}$ & $-0.01 \mathrm{~ns}$ & $0.21 \mathrm{~ns}$ & $0.44^{* *}$ & $0.31^{*}$ & $0.20 \mathrm{~ns}$ & $-0.10 n s$ & $0.17 \mathrm{~ns}$ & & $-0.18 n s$ & $0.38^{* *}$ \\
\hline EL & $-0.58^{\star *}$ & $-0.30 \mathrm{~ns}$ & $-0.51^{* *}$ & $-0.36 \mathrm{~ns}$ & $-0.36 \mathrm{~ns}$ & $-0.37 n s$ & $0.09 \mathrm{~ns}$ & -0.19 & -0.21 & & $0.07 \mathrm{~ns}$ \\
\hline SC & $0.63^{* *}$ & $0.70^{\star *}$ & $0.62^{* *}$ & $0.62^{* *}$ & & $0.59^{* *}$ & $0.27^{*}$ & $0.30^{*}$ & $0.03 \mathrm{~ns}$ & $-0.40^{* *}$ & \\
\hline
\end{tabular}

${ }^{* *} \mathrm{p}<0.01$; ${ }^{*} \mathrm{P}<0.05$; ns=Non-significant; BW=Body weight, $\mathrm{HG}=$ Heart girth, $\mathrm{WH}=$ Height at Withers, $\mathrm{BL}=\mathrm{Body}$ length, $\mathrm{PW}=\mathrm{Pelvic}$ width, $\mathrm{RH}=\mathrm{Rump}$ height, RL=Rump length $\mathrm{HL}=$ Head length, $\mathrm{EL}=$ Ear length, $\mathrm{TtL}=$ Teat length, $\mathrm{SC}=$ Scrotal circumference

Table 2: Correlation coefficients among body measurements and weight of females and males of indigenous sheep in the study area (values above the diagonal are for females and below the diagonal are for males) ( $N=60$ male; $N=540$ females).

other body measurements was in agreement with other results $[16,17]$ and it can indicate that chest girth is the best variable for predicting live weight than other measurements. Ear length had lower and negative correlation coefficients with body weight and other linear body measurements. The result was agreement with the report of Bafowethu for zulu sheep, there is negative correlation of ear length with body weight and other linear body measurements [18].

\section{Live body weight and linear measurements}

Body measurements are considered as qualitative growth indicators which reflect the conformational changes occurring during the life span of animals. Although live body weight is an important growth and economic trait, it is not always possible to measure it due to mainly the lack of weighing scales, particularly in rural areas. Body measurement can also be used routinely in weight estimation and selection programmes based on its utility in determining breed evolution trends [7].

Sex effect: The least square means and standard errors for the effect of sex and their interaction on body weight and other body measurement are presented in Table 3. Body weight and some other linear body measurements does not show significant different between sexes. For trait showing significance difference female were larger than male. The result is agreement with the finding of Abera for sheep type in Selale area female have larger linear body measurements than male counterpart [16].

Age effect: The size and shape of the animal increases until the animal reach its maturity and the effect of age on body weight and other body measurements were also observed indifferent sheep breeds of Ethiopia [19]. Body weight and all body measurements were significantly affected by age group except horn length. All the body measurements were increased as the age increased from the intermediate age group (1 PPI) to the oldest 4 PPI and greater age group. Similar finding was reported by Fasae who noted that body weight and body measurements increased with age of ewes for the first three years and then decreased slightly for ewes above four years [20].

District effect: District had a significant effect on body weight and all other linear body measurements. The finding is agreement with the report of Mesfin [17]. Results for body weight and linear measurement shows that Agarfa district had significantly larger $(\mathrm{P}<0.05)$ linear measurements than others sheep population.

Body weight values in rams and ewes of sheep types in the study area were $25.64 \mathrm{~kg}$ and $26.36 \mathrm{~kg}$, respectively. The finding was lower than the report of Solomon where the average adult body weight of
Arsi-Bale sheep was $28.6 \mathrm{~kg}$ [21]. The weight of ewes in this study $(26.36 \mathrm{~kg})$ was comparable with the report of Wossenie for Hararghae highland sheep [22]. The overall mean of body length, heart girth, wither height, pelvic width, ear length, rump height, rump length, rump width and head length were $48.75 \mathrm{~cm}, 71.4 \mathrm{~cm}, 62.1 \mathrm{~cm}, 16.32$ $\mathrm{cm}, 11.1 \mathrm{~cm}, 63.66 \mathrm{~cm}, 14.04 \mathrm{~cm}, 16.86 \mathrm{~cm}$ and $9.11 \mathrm{~cm}$, respectively.

\section{Regression analysis}

The knowledge of livestock weight assessment remains the backbone on which all animal production management practices are hinged [23]. Multiple linear regression analysis was carried out to predict live body weight of an animal. Regression of body weight over independent variables, which have higher correlation with body weight, was done to set adequate model for the prediction of body weight separately for each sex.

Comparable $\mathrm{R}^{2}$ values were obtained for all relationships existing between BW and other LBMs for both female and male sample sheep population. Thus under field conditions, live weight estimation using heart girth alone would be preferable to combinations with other measurements because of difficulty of the proper animal restraint during measurement and the low proportion of animals at each dentition classes as well.

In this study in order to develop the prediction equation, only three quantitative traits were selected in the prediction equation for ewes $(\mathrm{CG}+\mathrm{BL}+\mathrm{HL})$ and only four linear body measurements were taken to be incorporated in to the model for male $(\mathrm{CG}+\mathrm{SC}+\mathrm{RL}+\mathrm{PW})$ (Table 4). The fitted prediction model was selected with smaller value of $\mathrm{C}(\mathrm{p})$ and higher $\mathrm{R}^{2}$ values. Several authors in similar studies have concluded that heart girth can be used as a sole predictor of body weight due to high associate regression coefficients obtained [24]. The importance of HG in weight estimation demonstrated in the present study could be as a result of the fact that muscle, and some fat along with bone structure contribute to its formation [25]. From this study it is concluded that hear girth is the best sole predictors of body weight of sheep at farmers condition.

\section{Conclusion}

Planning of any breeding program including community based breeding strategy and /or breed improvement scheme needs the identification of genotypic and phenotypic traits of the particular sheep breed and also to know the genetic ability of that breed and the production environment that can influence productivity of the animal. 
Citation: Asefa B, Abate T, Adugna E (2017) Phenotypic Characterization of Indigenous Sheep Types in Bale Zone, Oromia Regional State, Ethiopia J Vet Sci Technol 8: 452. doi: 10.4172/2157-7579.1000452

Page 6 of 7

\begin{tabular}{|c|c|c|c|c|c|c|}
\hline Effect and level & BW & BL & HG & WH & PW & EL \\
\hline & LSM \pm SE & LSM \pm SE & LSM \pm SE & LSM \pm SE & LSM \pm SE & LSM \pm SE \\
\hline \multicolumn{7}{|l|}{ Over all } \\
\hline \multirow[t]{2}{*}{ CV } & $26 \pm 2.83$ & $48.75 \pm 3.28$ & $71.4 \pm 4.70$ & $62.1 \pm 3.87$ & $16.32 \pm 2.82$ & $11.1 \pm 1.08$ \\
\hline & 10.78 & 6.74 & 6.59 & 6.24 & 17.31 & 9.78 \\
\hline R2 & 0.12 & 0.29 & 0.18 & 0.13 & 0.20 & 0.18 \\
\hline District & * & * & * & * & * & * \\
\hline AGARFA & $27.25 \pm 0.2 a$ & $50.25 \pm 0.3 a$ & $73.50 \pm 0.42 a$ & $65.00 \pm 0.35 a$ & $17.68 \pm 0.25 a$ & $10.74 \pm 0.09 c$ \\
\hline DINSHO & $26.96 \pm 0.2 a$ & $50.55 \pm 0.3 a$ & $72.65 \pm 0.42 a$ & $61.04 \pm 0.35 b$ & $16.25 \pm 0.25 b$ & $10.44 \pm 0.09 d$ \\
\hline GOBA & $27.21 \pm 0.2 a$ & $50.57 \pm 0.3 a$ & $73.40 \pm 0.42 a$ & $62.21 \pm 0.35 b$ & $18.00 \pm 0.25 a$ & $10.90 \pm 0.09 c$ \\
\hline SAWENA & $24.92 \pm 0.2 b$ & $46.46 \pm 0.3 b$ & $69.06 \pm 0.42 b$ & $61.41 \pm 0.35 b c$ & $14.00 \pm 0.25 c$ & $11.54 \pm 0.09 c$ \\
\hline DK & $25.10 \pm 0.2 b$ & $45.93 \pm 0.3 b$ & $68.39 \pm 0.42 b$ & $60.65 \pm .35 c$ & $15.65 \pm 0.25 b$ & $11.83 \pm 0.09 a$ \\
\hline Sex & ns & ns & * & * & ns & ns \\
\hline Male & $25.64 \pm 0.38 a$ & $48.28 \pm 0.49 a$ & $68.47 \pm 0.65 b$ & $60.76 \pm 053 b$ & $16.90 \pm 0.40 a$ & $10.83 \pm 0.15 a$ \\
\hline Female & $26.36 \pm 0.2 a$ & $48.8 \pm 0.16 a$ & $71.73 \pm 0.21 a$ & $62.20 \pm 0.17 a$ & $16.25 \pm 0.13 a$ & $11.11 \pm 0.05 a$ \\
\hline Age group & * & * & * & * & ns & * \\
\hline $1 \mathrm{PPI}$ & $24.82 \pm 0.1 \mathrm{c}$ & $47.26 \pm 0.2 c$ & $68.74 \pm 0.32 c$ & $61.17 \pm 0.27 b$ & $16.39 \pm 0.21 a$ & $11.01 \pm 0.08 b$ \\
\hline 2 PPI & $26.57 \pm 0.2 b$ & $49.19 \pm 0.3 b$ & $71.86 \pm 0.42 b$ & $61.56 \pm 0.35 b$ & $16.75 \pm 0.27 a$ & $11.39 \pm 0.10 a$ \\
\hline 3 PPI & $27.15 \pm 0.2 a b$ & $49.55 \pm 0.2 a b$ & $72.88 \pm 0.37 b$ & $62.76 \pm 0.32 a$ & $16.08 \pm 0.25 a$ & $11.11 \pm 0.09 b$ \\
\hline$\geq 4$ PPI & $27.85 \pm 0.2 a$ & $50.25 \pm 0.3 a$ & $74.44 \pm 0.49 a$ & $63.62 \pm 0.42 a$ & $15.97 \pm 0.32 a$ & $10.80 \pm 0.12 b$ \\
\hline \multirow[t]{2}{*}{ Effect and level } & $\mathrm{RH}$ & $\mathrm{RL}$ & RW & $\mathrm{HL}$ & SC & \\
\hline & $\mathrm{LSM} \pm \mathrm{SE}$ & $\mathrm{LSM} \pm \mathrm{SE}$ & $\mathrm{LSM} \pm \mathrm{SE}$ & $\mathrm{LSM} \pm \mathrm{SE}$ & LSM \pm SE & \\
\hline Over all & $63.66 \pm 3.49$ & $14.04 \pm 1.22$ & $16.86 \pm 1.50$ & $9.11 \pm 0.81$ & $24.65 \pm 2.2$ & \\
\hline CV & 5.49 & 8.71 & 8.92 & 8.95 & 9.04 & \\
\hline $\mathbf{R 2}$ & 0.11 & 0.25 & 0.07 & 0.31 & 0.10 & \\
\hline District & * & * & * & * & * & \\
\hline AGARFA & $66.04 \pm 0.31 a$ & $14.95 \pm 0.11 a$ & $17.35 \pm 0.13 a$ & $9.90 \pm 0.07 a$ & $25.37 \pm 0.64 a b$ & \\
\hline DINSHO & $62.30 \pm 0.31 c$ & $13.41 \pm 0.11 \mathrm{c}$ & $17.25 \pm 0.13 a b$ & $9.13 \pm 0.07 c$ & $25.58 \pm 0.64 a$ & \\
\hline GOBA & $63.48 \pm 0.31 b$ & $13.00 \pm 0.11 d$ & $16.97 \pm 0.13 b$ & $9.45 \pm 0.07 b$ & $24.54 \pm 0.64 a b$ & \\
\hline SAWENA & $63.65 \pm 0.31 b$ & $14.50 \pm 0.11 b$ & $16.47 \pm 0.13 c$ & $8.77 \pm 0.07 d$ & $23.75 \pm 0.64 b$ & \\
\hline DK & $62.84 \pm 0.31 b c$ & $14.35 \pm 0.11 b$ & $16.25 \pm 0.13 c$ & $8.30 \pm 0.07 e$ & $24 \pm 0.64 a b$ & \\
\hline Sex & * & ns & * & ns & & \\
\hline Male & $62.53 \pm 0.47 b$ & $13.77 \pm 0.18 a$ & $16.0 \pm 0.19 b$ & $9.19 \pm 0.12 a$ & 24.65 & \\
\hline Female & $63.79 \pm 0.15 a$ & $14.07 \pm 0.06 a$ & $16.96 \pm 0.06 a$ & $9.09 \pm 0.04 a$ & - & \\
\hline Age group & * & * & * & * & ns & \\
\hline $1 \mathrm{PPI}$ & $63.20 \pm 0.25 b$ & $14.15 \pm 0.09 a$ & $16.44 \pm 0.10 c$ & $8.80 \pm 0.06 c$ & $24.42 \pm 0.35 a$ & \\
\hline 2 PPI & $63.69 \pm 0.32 b$ & $14.18 \pm 0.12 a b$ & $16.87 \pm 0.13 b$ & $9.33 \pm 0.08 \mathrm{ab}$ & $25.16 \pm 0.65 a$ & \\
\hline 3 PPI & $63.64 \pm 0.29 b$ & $13.86 \pm 0.11 b$ & $17.15 \pm 0.12 \mathrm{ab}$ & $9.15 \pm 0.07 b$ & $24.58 \pm 0.92 a$ & \\
\hline$\geq 4 \mathrm{PPI}$ & $64.75 \pm 0.38 a$ & $13.89 \pm 0.14 a b$ & $17.32 \pm 0.15 a$ & $9.45 \pm 0.09 a$ & $28 \pm 2.92 a$ & \\
\hline
\end{tabular}

Table 3: Live Body Weight and Linear Measurements in study area.

\begin{tabular}{|c|c|c|c|c|c|c|c|c|c|}
\hline Sex & Model & I & b1 & b2 & b3 & b4 & b5 & $\mathbf{R}^{2}$ & $\mathrm{CP}$ \\
\hline \multirow{3}{*}{ 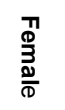 } & CG & -10.18 & 0.51 & - & - & - & - & 0.75 & 186.20 \\
\hline & $\mathrm{CG}+\mathrm{BL}$ & 13.69 & 0.39 & 0.25 & - & - & - & 0.81 & 10.38 \\
\hline & $\mathrm{CG}+\mathrm{BL}+\mathrm{HL}$ & -13.53 & 0.40 & 0.26 & -0.17 & - & - & 0.82 & 5.76 \\
\hline \multirow{4}{*}{$\frac{\mathbf{3}}{\frac{\mathbf{d}}{D}}$} & CG & -9.49 & 0.51 & - & - & - & - & 0.68 & 43.88 \\
\hline & $\mathrm{CG}+\mathrm{SC}$ & -12.22 & 0.39 & 0.43683 & - & - & - & 0.74 & 27.98 \\
\hline & $\mathrm{CG}+\mathrm{SC}+\mathrm{RL}$ & -14.41 & 0.38 & 0.38463 & 0.33 & - & - & 0.77 & 19.53 \\
\hline & $\mathrm{CG}+\mathrm{SC}+\mathrm{RL}+\mathrm{PW}$ & -13.66 & 0.41 & 0.39 & 0.27 & -0.11 & & 0.79 & 15.79 \\
\hline
\end{tabular}

Table 4: Multiple linear regression analysis of live body weight on different LBMs for male and female sheep in the study area.

The study was conducted in Bale zone oromia regional state of Ethiopia. Even though the study areas are rich in livestock resources including small ruminants, nothing has been done to characterize, identify and document theexisting indigenous sheep types and its production system.

The characterization of sheep in this study was helpful to livestock farmers and researchers in preserving the genetic resources of some of the indigenous Ethiopian sheep breeds, as well as to farmers/ pastoralists and dealers in livestock products in the production, processing and marketing of livestock and livestock products. The present study reveal that there is polymorphism, both in qualitative and morphometric traits, among sheep types in highland and low land, inferring considerable genetic variability. However, whether the variations in these morphological traits are caused by adaptive or nonadaptive sources needs to be further verified by comparing between relative levels of population divergence in quantitative traits and neutral DNA markers. 
Citation: Asefa B, Abate T, Adugna E (2017) Phenotypic Characterization of Indigenous Sheep Types in Bale Zone, Oromia Regional State, Ethiopia. J Vet Sci Technol 8: 452. doi: 10.4172/2157-7579.1000452

\section{Acknowledgements}

First of all authors would like to thank Madda Walabu University for allowing and funding budget to undertake the research activities. Special appreciation and thanks goes to the farmers/pastoralists of Agarfa, Dinsho, Goba, Sawena and Dawe kechan districts of Bale zone for their time devotion, providing necessary data and allowing their animals for body measurements.

\section{References}

1. Solomon G, Sisay L, Komen H, van Arendonk JAM (2007) Estimates of genetic parameters and genetic trends for live weight and fleece traits in Menz sheep. Small Rumin Res 70: 145-153.

2. Markos T (2006) Productivity and health of indigenous sheep breeds and crossbreds in the central Ethiopia highlands. Swedish University of Agricultural Science (SLU), Uppsala, Sweden.

3. Kosgey IS, Okeyo AM (2007) Genetic improvement of small ruminants in lowinput, smallholder production systems: Technical and infrastructural issues. Small Rumin Res. 70: 76-88.

4. Workneh A (1992) Preliminary survey of indigenous goat types and goat husbandry practices in southern Ethiopia. Alemaya University of Agriculture, Ethiopia, p: 153

5. Workneh A, Ephrem G, Markos T, Yetnayet M, Rege EO (2004) Current State of Knowledge on Characterization of Farm Animal Genetic Resources in Ethiopia. Proceedings of the 11th Annual conference of the Ethiopian Society of Animal Production.

6. Getahun L (2008) Productive and economic performance of small ruminan production in production system of the highlands of Ethiopia. University of Hohenheim, Stuttgart-Hoheinheim, Germany.

7. Riva J, Rizzi R, Marelli S, Cavalchini G (2002) Body Measurements in Bergamasca Sheep. Small Rumin Res 2: 221-227.

8. Kunene NW, Nesamvuni AE, Nsahlai IV (2009) Determination of predic equations for estimating body weight of Zulu (Nguni) sheep. Small Rumin Res $84: 41-46$

9. Afolayan RA, Adeyinka IA, Lakpini AM (2006) The estimation of live weight from body measurements in Yankasa sheep. Czech J Anim Sci 51: 343-348.

10. Yakubu A (2009) Fixing collinearity instability in the estimation of body weight from morpho biometrical traits of West African dwarf goats. Trakia J Sci 7: 61-66.

11. BZWP (Bale Zone Woreda Profile) (2008) Bale Zone Woreda Profile.

12. FAO (Food and Agriculture Organization of the United Nations) (1986) Animal genetic resources data banks-2. Descriptor lists for cattle, buffalo, pigs, sheep and goats. Animal Production and Health Paper No. 59, Volume 2. Rome.

13. Workneh A, Rowlands J (2004) Design, execution and analysis of the livestock breed survey in Oromiya Regional State, Ethiopia. OADB (Oromiya Agricultural Development Bureau), Addis Ababa, Ethiopia, ILRI (International Livestock Research Institute), Nairobi, Kenya.

14. Solomon G, Komen H, van Arendonk JAM (2008) Selection on linear size traits to improve live weight in Menz sheep under nucleus and village breeding programs. Livest Sci 118: 92-98.

15. Yakubu A, Salako AE, Imumorin IG, Ige AO, Akinyemi MO (2010) Discriminan analysis of morphometric differentiation in the West African Dwarf and Red Sokoto goats. S Afr J Anim Sci 40: 381-387.

16. Abera B, Kebede K, Gizaw S, Feyera T (2014) On-Farm Phenotypic Characterization of Indigenous Sheep Types in Selale Area, Central Ethiopia. J Vet Sci Technol 5: 180.

17. Mesfin A (2015) On Farm Phenotypic Characterization of Indigenous Sheep Types and their Production System In Wolaita Zone, Southern Ethiopia. Haramaya University, Ethiopia.

18. Bafowethu SM (2012) Phenotypic characterization of Zulu sheep: Implications for conservation and improvement. University of Zululand.

19. Tesfaye G (2008) Characterization of Menz and Afar Indigenous Sheep Breeds of Smallholders and Pastoralist for Desighing Community Based Breeding Strategies in Ethiopia. Haramaya University, Dire Dawa, Ethiopia.

20. Fasae OA, Chineke AC, Alokan JA (2006) Relationship between some Physical Parameters of Grazing Yankasa Ewes in the Humid Zone of Nigeria. University of Agriculture, PMB 2240, Abeokuta, Nigeria.

21. Solomon G (2008) Sheep resources of Ethiopia: genetic diversity and breeding strategy. Wageningen University, The Netherlands.

22. Wossenie SH (2012) On-Farm Phenotypic Characterization of Hararghe Highland Sheep and their Production Practices in Eastern Hararghe Zone, Ethiopia. MSc Thesis, Haramaya University, p: 140.

23. Otoikhian CSO, Akporhuarho AM, Oyefia OP, Isidahomen CE (2008) Body measurement parameters as a function of assessing body weight in goats under on-farm research environment. African J Gen Agricult 4: 1595-6984.

24. Taye M, Abebe G, Gizaw, S, Lema S, Mekoya A, et al. (2010) Traditional management systems and linear body measurements of Washera sheep in the western highlands of the Amhara National Regional State, Ethiopia. Livest Res Rural Dev 22: 169

25. Okpeku M, Yakubu A, Peters SO, Ozoje MO, Ikeobi CON, et al. (2011) Application of multivariate principal component analysis to morphological traits of goats in southern Nigeria. Acta Agric Slovenica 98: 101-109. 